\title{
ГРАТАНСТВО У ОКВИРИМА ЛИБЕРАЛИЗМА И КОМУНИТАРИЗМА: ИСТОРИЈСКИ РАЗВОЈ И ИНТЕРФЕРЕНЦИЈЕ 2
}

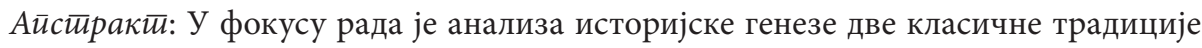
грађанства: комунитаризма и либерализма. Обе традиције свој настанак и темељне поставке дугују античким цивилизацијама (Грчке, односно Рима), али свој пун развој добијају у новом веку, кроз модерна филозофско-политичка разматрања. И комунитаризам и либерализам у новом веку биће важан предмет спорова и уградиће се у различите идеологије или ће са њима интерферирати током XIX и XX века, што и данас траје. Савремена плуралистичка друштва, међутим, указују на недостатност обе грађанске традиције онда када треба наћи повољна решења за грађанску инклузију различитих културних група и идентитета. Крај $\mathrm{XX}$ века наново оживљава интересовање за теорију грађанства, па се појављују бројни нови модели и теоријски предлози, међу којима и групнодиференцирано грађанство, као и други концепти, од којих се неки наводе у раду. Сви они представљају критички осврт на класичне грађанске традиције, али се, упркос томе, показује да се ниједан нови концепт теоријски нити практично не може сасвим изоловати од комунитаризма и либерализма и њихових идејних домета.
\end{abstract}

Кључне речи: Грађанство, комунитаризам, либерализам, политичка заједница, републиканизам.

\section{Увод}

Пре него што је промишљање грађанства у новим оквирима и теоријским могућностима постало актуелно крајем XX века, ова тема углавном се разматрала унутар две основне теоријске традиције: комунитарне и либералне. Оне ни данас нису превазиђене, али се наново валоризују и допуњују новим концептуалним оквирима. Разлике у схватањима појма грађанина потичу из његове сложености, као и различитих аспеката које ова фигура унутар себе носи (права, дужности, статус, чланство, партиципација, лојалност, идентитет), па

\footnotetext{
${ }^{1}$ jelena.bozilovic@filfak.ni.ac.rs

${ }^{2}$ Рад је настао у оквиру Интерног пројекта “Корак ка професионализацији социологије: анализа потреба за професијом”, који реализују Департман за социологију и Филозофски факултет у Нишу.
} 
отуд и унутрашњих напетости које се потом рефлектују и на теорију. Сажето речено, комунитарна традиција акценат ставља на чланство у политичкој заједници на чијем темељу следи учествовање у политичком животу што представља суштину слободе, док либерална мисао грађанина види најпре као носиоца права које држава треба да штити и сваком грађанину гарантује једнак третман. Комунитарна традиција има корене у античко-грчком разумевању односа грађанина и политичке заједнице, док се либерална концепција зачела у античком Риму, али је своје темеље изградила током новог века, унутар теорија природног права и друштвеног уговора и теорије либерализма. ${ }^{3}$ Ипак, за потпуније истријско-теоријске трансформације, у анализу је потребно узети и друге периоде, што нас наводи на разматрање идеје грађанства унутар грубе поделе на пет историјских раздобља.

Први период, који означава саме почетке рођења грађанина и грађанства, поклапа се са настанком полиса (оквирно, VII век п.н.е.), у коме је доминирала политичка димензија грађанства, односно схватање грађанина као некога ко захваљућујући врлинама руководи заједницом и брине о њеном општем добру. Затим следи друга велика епоха у доба античког Рима, где се поимање грађанина своди на правне оквире (статус), а дистанцира од његовог политичкоетичког значења које је обележило грчки полис. Оживљавање градова у другој половини средњег века може се узети као следећа, трећа историјска трансфромација, када се грађанин остварује унутар територијалне заједнице коју чини град-држава. Ипак, оно што ову релацију сада дефинише јесте економска, а не политичка димензија, па се на том нивоу средњовековни град-држава разликује од античког полиса. Наредних неколико векова водиће се борбе за политичку инклузију економски оснажених слојева, а тај процес паралелно биће праћен формирањем и јачањем националне државе. Такав ће развојни ток кулминирати формирањем концепта држављанства, када у XX веку грађанин постаје по основу националности сасвим изједначен са држављанином, што ће бити четврта трансформација у историји развоја грађанства. Крај XX века обележен је крупним друштвеним променама које су обновиле интересовање за студије грађанства, што је последично резултовало појавом бројних идејних струјања. Посебан изазов постају нове просторне арене које испливавају као оквири припадања, лојалности, привржености, иденититета и грађанске партиципације. Описани процес може се сматрати поводом настанка пете трансформације грађанства, унутар које се наново пропитују односи права и

\footnotetext{
${ }^{3}$ Посматрано из угла социолошке теорије, раздвајање класичних традиција грађанства може се довести у везу са разликом између заједнице и друштва, коју идеалнотипски утемељује Фердинанд Тенис (Tönniess). Заједница почива на доминацији колективне свести над појединцем и његовим изборима, обилује спонтаним, не тако формалним и крутим везама, већ односима прожетим солидарношћу, па чак и емоционалном блискошћу. Заједница се темељи на обичајима, религији и значају породице и блиских веза. Друштво, насупрот томе, представља већи колектив заснован на рационално-интересним основама, уговорима и индивидуализму. У друштву доминирају индустрија, право и политичко законодавство. Док заједница, по Тенису, представља организам, дотле је друштво механички агрегат (Tenis 1987: 235-241).
} 
дужности, и то преко појмова слободе, индивидуализма, политичке заједнице, космополитизма, национализма, патриотизма и свих других вредности које су на различите начине уткане у либерализам или комунитаризам, и проблематизоване унутар истих. Не само кроз последњу, већ кроз свих пет наведених историјских раздобља преламала су се важења концепта грађанства која су нагињала ка једној од струја на релацији класичних грађанских традиција.

Циљ овог рада није да детаљно прикаже сваку од наведених епоха, већ да у упоредној перспективи да̂ обрисе комунитарне и либералне традиције промишљања грађанства, смештајући их у дате историјске оквире.

\section{Комунитаристичка традиција и античка грчка}

Комунитаризам као коцепција уређења грађанства заснива се на уверењу да је колективни идентитет примарни и наткриљујући унутар политичке заједнице и да као такав представља основну везивну нит међу појединцима и групама. Не постоји појединац који може бити сасвим изолована индивидуа, одвојена од друштвено-културног контекста коме припада. Сваки појединац увек израста у одређеном културном и вредносном миљеу, па је либерално инсистирање на независној индидвидуи по комунитаристима више мит, него реалност. При томе, комунитаристи насупрот либералима не сматрају да постоје универзални стандарди праведне заједнице, нити општег добра, већ ове појмове они сагледавају контекстуално. Сваки колектив, наиме, сам одлучује какав ће начин живота изабрати као пожељан и одредити га као парадигму за сопствене чланове. Овакав критички тон нарочито се појачао осамдесетих година прошлог века, и то као реакција на либералну доктрину изнету од стране Џона Ролса (Rawls).

Комунитаристчка теорија грађанства, иако припада XX веку, своје идеје црпе из антике и грчког полиса, као и филозофских концепција које на овом тлу настају у исто време. Будући да прва социјално-филозофска мисао датира од око VI века п.н.е. (са почецима антрополошког раздобља у филозофији), може се рећи да су прва промишљања идеје грађанина нераздвојна од полиса као његовог основног територијално-политичког оквира. Грађанин схваћен као политички субјект у античко-грчком поимању био је носилац ethosa који је значио да пре него што добије политичка права он мора поседовати изграђен морални фундус за заједницу, који ће потом кроз политичко деловање даље исказати залагањем за опште добро. ${ }^{4}$ Стога се дефинисање општег добра сматра једним од централних места комунитаристичког схватања заједнице и грађанства. На тај начин, у основи комунитаристичке концепције стоји онај појединац који није само приватна личност која остварује права унутар државе, већ

\footnotetext{
${ }^{4}$ Дужности у концепцији античке Грчке стајале су испред права, али и иза њих. Грађанска политичка права појединац би добијао на темељу већ исказаних лојалности држави, као што је војна служба, али би дужност према држави наставио да демонстрира и након стицања права, кроз активни политички ангажман за добробит читавог полиса.
} 
je, бивајући грађанином, он и политичко биће које активно партиципира у друштвеном животу. Грађанин (polites) је, дакле, схваћен као појединац који је по природи друштвено биће које своје потенцијале остварује кроз политички ангажман (kata physin zoon politikon).

Античко-грчки модел грађанства као одраз комунитаристичког схватања имао је своје специфичности које су произлазиле из форме територијално-политичке организације. Основни модел античке организације друштва био је полис, односно град-држава, који је представљао утврђену заједницу чији је број становника варирао од неколико хиљада до неколико стотина хиљада. ${ }^{5}$ Како Покок (Pocock) примећује, политичка заједница античког полиса изградила се на темељу тога да је говор сада постао важнији од крвног сродства, а чин доношења заједничке одлуке грађ)ана важнији од чина освете (Pocock 1995: 30). Полис је сачињавала територија градског језгра са околним селима. Број становника и грађана у њему био је важан из економских и политичких разлога. Аристотел у седмој глави “Политике" посебно апострофира то да број становника не сме бити премали, баш због економске самодовољности (autarkia), али такође ни превелики, јер се људи морају познавати да би међусобно градили поверење и на темељу тога заједнички деловали у корист јавног интереса (Aristotel 1970: 229 [13266]). Тек на темељу таквих вредности полис се могао сматрати заједницом (koinonia) (економском, политичком и културно-религијском), а ова је заједница стајала изнад појединца. Такав став репрезентује и Перикле, који је обраћајући се грађанима Атине, тврдио да је важније благостање полиса, него његових чланова, јер се само стабилношћу и срећом заједнице, може поправити и благостање појединца (Mićunović 1997: 17). Кристализација колективних вредности и општег добра остваривана је у законима полиса, који су сматрани врхунцем колективне мудрости и моралности, а непоштовање закона, као и њихово непостојање схватано је као врхунски одраз неморала. ${ }^{6}$

Оно што подразумевамо под комунитаристичким вредностима античке Грчке прожимало је свакодневни живот, васпитање и јавни морал. Описујући полис као суверену милитаристичку заједницу, Вебер (Weber) преноси да су грађани старе Грчке били кажњавани уколико се као домаћини не би односили одговорно према својој имовини или су живели расипничким животом (чиме демонстрирају непостојање осећаја за праву меру). Бити добар и одговоран супруг такође је била важна вредност, као и одгој деце и поштовање родитеља. Уколико се неки грађанин не би добро показао у овим дужностима, сматрало

\footnotetext{
${ }^{5}$ Било је и изузетака, па се наводи да је Микена у једном тренутку своје историје имала свега неколико стотина становника.

${ }^{6}$ Овај неморал везивао се како за појединца, тако и за поједине владавине. Проучавању државних уређења антички филозофи придавали су посебну пажњу, а основни критеријум њиховог разликовања чинио је управо елемент општег добра. У складу с тим, најгором влашћу сматрана је тиранија, јер почива на сили и гледа само интерес владара, али је непостојање закона такође сматрано једним од најопаснијих стања. Стога не чуди што се анархија свуда одређује као најнепожељније друштвено стање.
} 
се да га треба санкционисати јер угрожава грађански поредак и врлину. Стога, у Атини се није могло живети по сопственим правилима, а имовина је лако могла бити одузета као казна за дуговање. При том би и личност појединца могла бити отуђена са имовином, што је у неким случајевима значило падање у ропство (Veber 1976: 415).

Етичко схватање фигуре грађанина кроз политички ангажман врхунац доживљава у Аристотеловом схватању циља државе, који се огледа у срећном животу (а не пуком опстанку). ${ }^{7}$ Да би се такав циљ постигао, Аристотел пред оне који имају навишу власт (а то су грађани) поставља строге захтеве, што моралног типа, што оне правно-формалне. Тиме Аристотел наставља Платонову идеју да свако постоји (најпре) ради државе, а не ради себе самог. Аристотелова теорија о грађанину, коју износи у трећој књизи “Политике”, заснива се на схватању грађанина као оног који своју улогу остварује у обављању јавних послова, односно саветодавне и судске власти (Aristotel 1970: 72 [12756]). Такође, грађанин мора испуњавати услов да поседује домаћинство у коме се остварује рад робова и жена, којим се задовољавају егзистенцијалне потребе. Тек услов ослобођености од материјалне продукције грађанина чини слободним и спремним за политички ангажман са осталим грађанима полиса са којима је једнак (Види Pocock 1995: 31-2). ${ }^{8}$ Поред набројаног, важна одлика грађанина је и то да он мора бити неко коме се зна лоза, односно порекло. ${ }^{9}$

\section{Развој либералне грађанске традиције}

Либерализам као друга основна традиција разматрања грађанства, такође има несумњиви допринос у његовој изградњи. Идеја слободе која је у сржи овог схватања, захваљујући либералним концепцијама, кроз нови век успела је да постане једна од основних вредности на којима се градило будуће друштво. У центру либералног концепта грађанства сажима се идеја да је појединац као грађанин онај који чланством у држави ужива одређена права, а политички оквир који та права обезбеђује је држава. ${ }^{10}$ Дакле, грађански идентитет овде

\footnotetext{
${ }^{7}$ Различити полиси неговали су различите врлине. У Спарти, на пример, највећом врлином сматран је партиотизам и са њим повезана храброст, док су се у Атини испред свега стављале мудрост и разборитост, и са њима скопчане правда и умереност коју је појединац требало да исказује у сваком аспекту живота, што се потом преливало и на колектив.

${ }^{8}$ Једнакост грађана превасходно се тицала једнакости пред законом (isonomia), једнакост могућности говора (isagoria) и право на једнаку надницу за рад у јавним установама (isotimia) (Podunavac 2001: 24).

${ }^{9}$ Грађански статус био је наследног карактера, међутим, у полисима су постојале праксе доделе грађанства оном појединцу који би учинио неки подвиг или добро дело од којег би бенефит имао читав полис (Наjn 2010: 157).

${ }^{10}$ У каснијој фази развоја либерална теорија грађанства здружује се са идејама репрезентативне демократије и владавине права, односно грађанина уклапа у систем правила и процедура пред којима су сви једнаки.
} 
није превасходно схваћен политички, већ правно-формално; грађанство је мање колективно-политички механизам, а више индивидуално-економска активност коју обезбеђује држава (Podunavac 2001: 100). Било би, међутим, погрешно либералну доктрину схватити вулгаризовано, као идеологију која наглашава искључиво приватне интересе и не мари за заједницу. Напротив, либерални мислиоци управо наглашавају да је заједница неопходна и да је та заједница држава - стога они појединца не виде као изоловано егоистично биће које следи само сопствене инетресе. Супротно томе, индивидуа постоји и делује унутар колектива, али се наглашава да индивидуални идентитет мора бити одвојен и аутономан у односу на колективни и да ова аутономија мора бити правно заштићена. Либерализам такође не негира ни партиципацију, али не сагледава човека као тотално политичко биће. ${ }^{11}$ Осим тога, либерали прихватају значај грађанске врлине, али је она овде схваћена у нераскидивој вези са добробити индивидуе: либералне врлине, пођеднако су грађанске и личне врлине (Podunavac 2001: 115).

Грађанска концепција либерализма свој извор има у праксама у римској држави, али свој темељ добија тек у нововековној политичкој филозофији са изградњом модерне државе.

Римска држава почивала је на другачијим вредностима и институцијама од грчких полиса, које су се (вредности) пре свега базирале на практичним потребама, па се ова логика утиснула у схватање и уређење једначине грађанства. Грађанин је превасходно pater familias, који грађански статус стиче рођењем, усвојењем или додељивањем таквог права од стране државе. Пред крај републике, односно пред сам крај старе ере, фигура римског грађанина подразумева појединца који има право да стиче имовину, ступа у брак са женама из грађанских римских породица, тргује, бива заштићен законом за своје делатности, такође има право да му се суди по римским законима и у римском суду (Vasiljević 2016: 31). Грађанство у Риму било је у тесној вези са стицањем, поседовањем ствари и међуљудским трансакцијама, због чега је превасходно било везано за правни систем. ${ }^{12}$ И у античкој Грчкој грађанин је био део правог система, али је важнија од тога била морална димензија за колективно деловање са другим грађанима (што у Риму није био случај). Овде се грађанство односило пре свега на систем законске заштите приватних интереса, због чега се може рећи да се схватање грађанства померило са zoon politikon-a ка legalis hommo и да је фигура грађанина у Риму заправо била комбинација економске моћи и права (Pocock 1995: 38).

С обзиром на то да је Рим био имеператорска држава, временом је додела грађанског статуса престала бити ексклузивистичка и могла се лакше добити,

\footnotetext{
${ }^{11}$ Комунитарно-либерални спор могуће испратити и компарацијом позитивне и негативне слободе (Више о томе у Berlin, 1992).

12 Док је грађанин грчког полиса одражавао идеал човека као мислећег, ангажованог, моралног, друштвеног, интелектуалног и политичког бића, дотле је грађанин Рима биће које ступа у активне односе са другим људима и поседује ствари, а све ове активности заокржене су правном нормативом (Pocock 1995: 34).
} 
а додељивана је чак и робовима. Врхунац такве политике представља законик из 212. године нове ере, познат као Constitutio Antoniniana (Каракалин едикт), а разлози његовог доношења били су крајње практичне природе. Гломазној римској држави било је потребно новца од пореза, као и војника, а ове дужности биле су обавезе сваког ко је поседовао држављански статус. Политичка права, међутим, остаће ексклузивна привилегија и затворена унутар аристократских кругова. ${ }^{13}$ Зато се држављанство новим категоријама додељује као држављанство без права гласа и права на учешће у јавним државним функцијама. Треба напоменути и још једну важну разлику у односу на Грчку, а то је да се овде се бављење политиком није сматрало моралном обавезом, већ је схватано као ствар личног избора, што указује на оштри разлаз између старе Грчке и старог Рима, али истовремено и на две традиције грађанства које су се у њима оствариле: комунитаристичку и либералну.

Римска формула грађанства, заснована на правном нормативу, која грађанина одређује као онога ко живи у свету ствари, стиче их и њима располаже, вековима касније постаће главна парадигма либералне традиције грађанства (Pocock 1995: 43). Зато следећом важном степеницом у доприносу историјске изградње либералне традиције сматрамо почетак новог века и уздизање вредности индивидуализма. Томе је допринела нова економска култура која се почела појављивати већ у последњих неколико векова средњег века у градовима државама на Медитерану, а чији су носиоци били економски независни и предузетнички успешни појединци, пре свега занатлије и трговци. Осим економске еманципације средњовековног грађанства, индивдуализму је утиран пут и од стране номинализма, односно номиналистичке филозофије с краја средњег века. Ова струја мишљења испливала је као одраз средњовековног спора око универзалија, односно егзистенције општости. Основне црте номинализма огледају се у идеји да универзалности нису реално постојеће (представљају само имена), из чега је следио и став да заједница и на њој утемељено опште добро немају реални, још мање универзални значај. Главна референца у односу на коју и држава добија свој смисао је индивидуа, док држава постоји само ради појединца и његовог добра и циљ јој је једино у томе да штити његове интересе. Описане промене у схватањима доживеће кулминацију у приватизацији моралности (Vujačić 2002: 275), што ће постати базична интегрална идеја либералне концепције грађанства.

Једна од првих утицајних нововековних теорија која се сматра зачетком либерализма јесте теорија Томаса Хобса (Hobbes). Због идеја изнетих у „Левијатану“, по којима држава као суверен има апсолутна права, а грађани су

\footnotetext{
13 Грађанство у пуном смислу подразумевало је и право на учествовање у политици, али оно није било на нивоу обавезе. Сматрало се часним узети се државничких послова, али појединци су то чинили тек након задовољења материјалних потреба и стицања богатства, које је остало на првом месту: „Бављење државним пословима и руковођење врлинама правде и једнакости више није била ствар несебичног алтруизма, него рационалног интереса, који је у економској сфери углавном постигао оно што је могао (богатство) и сада потребује нову сферу (част) у којој би нашао задовољење“ (Molnar 2004: 18).
} 
схваћени као поданици, Хобсов концепт државе неки су видели као тоталитаран. Ипак, у његовој мисли могу се наћи зачеци и оног дискурса који указује на нововековну промену у вредносном систему у правцу либерализма. Хобс, наиме, право на рад и стицање радом одређује као једно од три основна права које суверен мора гарантовати поданику (Hobs 2006: 94-95), чиме се уоквирује либерално (буржујско) схватање грађанина. Овој парадигми још више ће допринети друге теорије код којих су либералне вредности заступљеније, но код Хобса. Једна од таквих је и мисао Џона Лока (Locke). Сврставајући у три основна природна права човека право на имовину (Lok 1978: 23), Лок гради виђење државе која за циљ има једино да такво право појединцу гарантује. ${ }^{14}$ Просветитељство ће такође уздизати дух трговине (што се највише може видети у Монтескјеовом “Духу закона”) 15 и индивидуализам, и то кроз афирмацију образованог појединца као критичког субјекта. На описаним традицијама током наредних векова изграђиваће се либерализам, као једна од доминатних матрица уређења капиталистичких друштава заснованих на национално-државном оквиру, али и доминатна једначина уређења концепта грађанства-држављанства.

\section{Нововековне интерференције и савремене концептуалне} критике и надградње

Богата социјална мисао новог века изнедриће и другу струју мишљења, која ће либералне претпоставке критиковати и доводити у питање. Јавна ствар (res publica) основно је везивно ткиво сваке политичке заједнице и основни кохезивни фактор сваког друштва. На темељу концепта опште воље, Русо (Rousseau) hе заснивати републиканизам, као филозофско-политичку концепцију која опште добро настоји да врати у фокус, придајући му примарни значај у односу на појединца.

Републиканизам почива на тврдњи да јавно добро надилази све партикуларитете у заједници, а да појединци морају ставити по страни личне интересе (нарочито тежњу ка богатству), онда када су колективни интереси заједнице у питању. Такав егалитарни дух провејава посебно кроз дела двојице мислилаца који се сматрају пионирима модерног републиканизма: Макијавелија (Machiavelli) и Русоа. Обојица аутора износе захтев за једнакошћу и ублажавањем социјалних разлика које би разарале темеље праведне и стабилне политичке заједнице која је ту да брине о својим грађанима (Jakopec 2019: 46). У ширем смислу, ради се о афирмацији једне више вредности која прожима републиканизам и за коју се слободно може рећи да представља темељ његове

14 Пратећи теорије природног права и друштвеног уговора из којих израста либерализам, примећујемо да је претполитичко стање је кључна сфера из којих се црпе аргументацију за оправдање либералних теза.

${ }^{15}$ Види у Monteskje 2011: 45. 
грађанске коцепције, а то је врлина. Да би једна политичка заједница изградила сопствени концепт општег добра и била стабилна, њени чланови (грађани) морају бити носиоци социјалног духа и страсти који скупа својим садржајем одговарају интересу политичке заједнице коју чине. Грађанска врлина је нешто што се стиче васпитањем, а у аргументацији овакве тврдње предњачи Русо који тврди да сваки појединац љубав према отаџбини, законима и слободи мора посисати заједно са мајчиним млеком (Види Đentile 2009: 69). Дакле, партиотизам је основни друштвени лепак који везује појединце међусобно, али и појединце са друштвеном заједницом. Уколико привржености домовини у друштву нема, њему прети растакање на атомизоване егоисте који себично следе сопствене интересе. Грађане, дакле, мора везивати одређена врста колективне емоције, а не страх од санкција. Такав републиканистички став уједно је и критика упућена либерализму.

Републиканизам је становиште које, иако својеврсно, има додира са обе традиције промишљања грађанства које су у фокусу овог рада. Републиканизам са комунитаризмом успоставља везу на плану афирмације јавних грађанских дужности испред права, што повлачи нужност постојања политичке заједнице. ${ }^{16}$ Једна од најзначајнијих ауторки која заступа схватање грађанина као делатног појединца јесте Хана Арент (Arendt). Она, као и Русо, истинску демократију види као директну, јер једино ова форма пружа могућности за демонстрацију свих потенцијала и врлина грађанске личности. Партиципација, дебата, расправа и опште добро могући су само унутар јавног простора директне демократије. Репрезентативна демократија убија политичко у грађанину, а грађанина нема уколико се не остварује као политичко биће. Уколико се та клица у њему потисне, остаје деполитизовани појединац вођен сопственим интересима, удаљен, како од идеала општег добра, тако и од сопствене слободе. Стога слобода и политичко деловање чине јединствено језгро грађанина (Arent, 1998). ${ }^{17}$

Иако је републиканска традиција ближа комунитаристичкој када је грађанство у питању, она има додирних тачака и са либерализмом. Обе традиције, наиме, наглашавају важност приватне сфере и слободе избора коју држава мора да омогући законима. Ипак, републиканизам даје већи значај политичкој заједници и политичкој партиципацији и почива на тврдњи да, уколико не постоји осећај за заједницу, а тиме и за опште добро, грађани постају пасивни и незаинтересовани за поредак, што отвара могућности за урушавање индивидуалне слободе и манипулацију од стране политичке класе. Стога се по републиканизму приватна слобода штити управо осећајем за заједницу од стране појединаца који је чине (Sládeček 2001-2002: 183). По либералима, међу-

\footnotetext{
16 Политичка заједница као оквир грађанске партиципације може бити држава, град, па и општина.

17 И комунитаризам и републиканизам, дакле, потенцирају партиципацију, али док комунитаризам наглашава друштвену, републиканизам акцентује политичку партиципацију. Управо у томе лежи једна од основних разлика ових традиција (Види Vujačić, 2007).
} 
тим, у друштву постоји више концепција општег добра, а држава не сме наметати једну од њих. Институције власти не смеју бити наклоњене било којој партикуларној идеји и морају остати неутралне. На појединцима је да сами одреде своју концепцију добра, а такво право на избор треба да штите закони државе. Они, дакле, морају бити негативни, односно одређивати шта је забрањено и на тај начин отварати слободно поље избора појединцима о томе каквим ће вредностима и интересима бити привржени (Vujačić 2002: 281; Vujačić, 2007).

Историја социјалне и политичке мисли XIX и XX века сведочи о томе да је свака од концепција имала свој развојни ток који је интерферирао са различитим друштвено-политичким системима и идеологијама, што се потом рефлектовало и на саму теорију. ${ }^{18}$ Либерализам је већ почетком XIX века испливао као доминантна идеологија капиталистичког друштва у настајању, пре свега у његовој економској димензији, док ће се његова политичка димензија, инкорпорирана у ширење грађанских права и политичку инклузију грађана, развијати спорије кроз читав XX век. Док је либерализам имао тесне везе са вредностима просветитељског покрета, дотле би се могло рећи да је комунитаризам имао идејну блискост са противпросветитељским покретом- романтизмом. Концепција појединца из угла обе традиције (комунитаризма и романтизма) заснива се на схватању да је он продукт друштвене интеракције и културе. Способности које од човека чине биће sui generis продукт су управо друштвених односа и друштвених пракси, те либерално позивање на појединца који би био независан од читавог друштва није у складу са самом суштином човека (Matulović 1995: 92). Комунитаризам је, такође, своје уточиште налазио у идеологијама конзервативизма, као и социјализма. Са конзервативизмом га повезује схватање о примату заједничке културне основе политичке заједнице и значаја поретка, патриотизма, традиције и породице за једно друштво. Ипак, највише веза комунитаризам остварио је са комунизмом, јер је код оба идеја заједнице од примарног значаја. Током XX века заједница је на левим политичким пларформама “коришћена” онда када је требало оправдати залагање за државу благостања и мере редистрибутивне политике, док се с десна позивање на заједницу и данас може чути онда када се она наводи као извор колективног моралног ауторитета који треба да сачува традицију од напада оних начина

\footnotetext{
${ }^{18}$ Један од најутицајнијих представника либералне доктрине XX века свакако је Ролс. Либералном аргументацијом аутор гради концепт друштвене правде која, по њему, мора бити темељ сваке политичке заједнице (Rols, 1998). Ипак, Ролсов либерални дискурс није прошао незапажено код комунитариста, па се динамика сукобљених аргументација две класичне грађанске традиције узбуркала почетком осамдесетих година XX века, што је обогатило друштвену мисао. Комунитаристички критички тон допирао је од стране Чарлса Тејлора (Taylor), Мајкла Волцера (Walzer), Мајка Сандела (Sandel) i Аласдера Мекинтајера (McIntyre), нарочито у погледу Ролсове либералне идеје о неутралности заједнице, али и других питања (Svift 2008: 158). Такође, од осамдесетих година критике либералне коцепције уређења друштва тицале су се и примедбе да је свођење грађанства на правни статус (гласање и плаћање пореза) за исход имало деполитизацију грађана, запостављање важности друштвеног и политичког ангажмана (који, такође, мора бити једнако важан елемент грађанства) и препуштање политике класи професионалних политичара (Vasiljević 2016: 49).
} 
живота који (наводно) штете друштву (одбрана хетеросексуалности, на пример) (Svift 2008: 159).

На крају крајева, ни једна од концепција у савремено доба није остала доследна својим идеалима, јер тако нешто није ни могуће. Стварност и друштвени живот увек су далеко сложенији и измичу свим тврдим оквирима у које теорија покушава да их уклопи. Управо се због тога и либерализам и комунитаризам међусобно налазе у односима интерференције. Као што, рецимо, комунитаризам одступа од неких својих постулата прихватајући либерално-демократску идеју о индивидуалној слободи и изборима, тако и либерализам прави компромисе са комунитаризмом. Свифт ово илуструје примером о увиђању неких заговорника либерализма о проблематичности неутралности државе, због чега се сам либерализам “цепа” на неутралистички и перфекционистички. Овај други либерализам далеко је ближи комунитаризму но изворном либерализму у погледу поимања могућности неутралности државе (Svift 2008: 188). Изречено потврђује и Ђорђе Павићевић, који сматра да ниједна од наведених концепција грађанства није успела да реши загонетке модерних плуралистичких друштава, што захтева и повлачи реинтерпретације унутар самих концепција (Pavićević 1997: 34). Поред компромиса и одступања од неких својих начела, занимљиво је, такође, испратити и здруживање либералне и комунитарне концепције које видимо на плану развоја капиталистичке националне државе. Баш као што је економски либерализам као своју подршку имао потребу за јаком законски уређеном националном државом, која би била његов територијално-политички оквир, тако су се и нека комунитаристичка начела, попут оног о чврстом заједничком идентитету политичке заједнице, остварила управо кроз идеју нације и национализма, који су постали кључни колективни идентитет концепта грађанства (заснованог на држављанству) од XIX, а највише током XX века.

Значајно је на овом месту споменути и неке савремене концепције грађанства, које представљају својеврсну допуну, али и критику класичних грађанских традиција. Вил Кимлика (Kymlicka) уважава либералну концепцију грађанства, али је допуњује идејом о троделном пакету групно диференцираних права која би била моћна правна грађанска регулатива у мултикултурним друштвима (Више у Vasiljević, 2016). Оштрији тон упућен либерализму долази од стране диференцираног грађанства, који се заснива на тврдњи да права морају бити групна, а не индивидуална (Jang, 2005). Универзалност и уздизање од свих идентитетских партикуларности које прокламује либерализам, условио је настанак лажно неутралног друштва и ситуацију да културне посебности остану занемарене или невидљиве. Атомизација друштва на изоловане појединце од који свако треба да следи сопствену концепцију општег добра звучи примамљиво, али у пракси заправо резултује маскирањем групних интереса са којима су појединци на одређени начин нужно скопчани. Зато Ирис Мерион Jанг (Young) сматра да би требало оформити нови сет права за сваку дефаворизовану друштвену групу којим би се оне кроз разне механизме партиципације 
могла укључити у друштво. Ипак, иако је овде превасходно на удару критика либерализам, није сасвим јасно ни како се комунитаристичка традиција “сналази” са плурализмима у друштву. Инистирање на примарности једног идентитета (као што је нпр. национализам) или монистичке визије општег добра политичке заједнице, свакако није компатибилно са мултикултурном реалношћу савременог света. Уколико би се комунитаризам приклонио варијанти постојања мултипликованих варијанти општег добра, односно равноправном постојању више кутлурно-идентитеских парадигми, онда би он, условно речено, могао бити ближи концепцијама које заговарају аутори окупљени око идеје групнодиференцираних права.

Својеврсну критику традиционалних концепата представљају и идеја радиканог плурализма Шантал Муф (Mouffe), као и уставни патриотизам Јиргена Хабермаса (Habermas). Муфова покушава да превазиђе недостатке либерализма и комунитаризма, али истовремено и да од обе узме оно што сматра валидним и применљивим за савремено друштво. На тај начин она грађанство не постулира само као један од могућих идентитета (што чини либерализам), нити га види предоминантним у односу на друге (као што то наглашавају комунитаризам, али и грађански републиканизам). Овде радикални плурализам јесте формула која се прилагођава савременом плуралистичком друштву, видећи грађанство као оквир који са једне стране омогућава да појединци следе различите концепције слободе и општег добра, али уз постојање услова за комуникацију и упућеност једних на друге (што у овој концепцији представља својеврсно опште добро) (Podunavac 2001: 153). Синтеза републиканизма и либерализма уз наглашавање комуникације пристутна је и код Хабермаса. Он уважавање индивидуалне слободе види као основну претпоставку демократије, али истиче и неоходност постојања једне наднационалне грађанске културе која би била гарант њеног важења. Цивилно друштво у теорији комуникативног деловања постаје основни социјални простор комуникације, расправљања политички и морално једнако вредних субјеката, а процедурална правила овог политичког процеса (реципроцитет, публицитет, одговорност) гарантују легитимност донесених одлука. ${ }^{19}$

\section{Закључна разматрања}

Последња промишљања грађанства тичу се израстања бројних нових концепата грађанства. Иако веома разнородни, заједничко им је настојање да скрену пажњу на партикуларне запостављене друштвене категорије и концепт грађанства учине комаптибилним са савременим друштвом у глобализацији. Фокусирајући се на групе које виде искљученим, они указују на то да је друштвени живот и даље дубоко прожет неједнакостима и неправдама, а да

19 Више о примени принципа уставног партиотизма на европску заједницу видети у Habermas 1995: 255-283. 
многовековно промишљање концепције грађанства у пракси није довело до успостављања инклузивног друштва. Неки од нових концепата грађанства су феминистичко, које се бави питањем историјске искључености жена из грађанских права и његовим савременим формама. Њему блиски концепти су интимно и сексуално грађанство, који се, грубо речено, фокусирају на анализу права грађана у домену приватности и интимности. Наднационализација друштвених и политичких институција и културе резултује потрагама за моделом грађанства који би уредио односе растућег броја странаца, односно мобилних, детериторијализованих грађана и држава у којима (повремено) живе и које посећују. Концепти који покрећу ове и сличне теме су европско, космополитиско, постнационално, мобилно, мањинско грађанство и други. Свакако вреди споменути и све присутнији концепт еколошког грађанства, који се бави питањем грађанских права и одговорности, акцентујући највише права на живот грађана у здравој животној средини, заштиту животне средине по себи, али и несразмеру у домену права и одговорности која постоји на плану активности великих компанија у конкретним срединама. ${ }^{20}$

Упркос бројним новим моделима грађанства, као и доприносу који дају и критикама које им се упућују, чини се да либерализам и комунитаризам као класични концепти грађанства остају базични и незаобилазни оквири свих новијих разматрања фигуре грађанина и позиције поједница и група унутар политичке заједнице. Зато се питања, теме и захтеви које покрећу нови концепти грађанства не могу разматрати као сасвим изоловани од традиционалних оквира (комунитаризма и либерализма), већ само у интерференцији са њима.

У сваком случају, прича о концепцијама грађанства, па и либерализму и комунитаризму који су у фокусу овог рада, не назире се крај. И након много векова, што политичко-филозофског промишљања, што политичке праксе, једначина грађанства није решена. Зато се намеће закључак да је промишљање концепта грађанства остаје вечита инспирација и изазов, али и више од тога. Овај задатак у плуралистичким и глобализованим друштвима једна је од највећих политичких потреба.

\section{Литература}

Arent, Hana (1998) Izvori totalitarizma. Beograd: Feministička izdavačka kuća.

Aristotel (1970) Politika. Beograd: Kultura.

Berlin, Isaija (1992) Četiri ogleda o slobodi. Beograd: Nolit.

Božilović, Jelena (2017) Urbano građanstvo: koncept i praksa. Beograd: Filozofski fakultet, Univerzitet u Beogradu. Doktorska disertacija.

Đentile, Emilio (2009) Religije politike. Beograd: XX vek.

Habermas, Jürgen (1995) "Citizenship and National Identity: Some Reflections on the

\footnotetext{
${ }^{20}$ Више о теми нових концепата грађанства у Božilović, 2017. и Vasiljević, 2013.
} 
Future of Europe" In: Beiner, R. (ed). (1995) Theorizing citizenship. New York: State University of New York press, pp. 255-283.

Hajn, Diter (2010) Istorija - Leksikon pojmova. Beograd: Clio.

Hobs, Tomas (2006) Čovek i građanin. Beograd: Hedone.

Jakopec, Petar (2019) Liberalizam i republikanizam: Lockeovo i Rousseauovo razumijevanje političke zajednice. Zagreb: Filozofski fakultet, Sveučilište u Zagrebu. Doktorski rad.

Jang, I. M. (2005). Pravednost i politika razlike. Zagreb: Naklada Jesenski i Turk.

Lok, Džon (1978) Dve rasprave o vladi. Beograd: Mladost.

Matulović, Miomir (1995) "Liberalizam, komunitarizam ili republikanizam: kritičke primjedbe uz Petittovu odbranu republikanizma”. U: Politička misao, Vol. XXXII, No. 1, str. 89-98.

Mićunović, Dragoljub (1997) Socijalna filozofija: ogledi. Beograd: Filip Višnjić.

Molnar, Aleksandar (2004) „Građanin“, U: Kritički pojmovnik civilnog društva (II)“. Krstić, P. (ur), Beograd:Grupa 484.

Монтескје, Шарл де (2011) Дух закона. Београд: Завод за уџбенике.

Pavićević, Đorđe (1997) “Komunitarno-liberalni spor u savremenoj filozofiji”. U: Filozofija i društvo IX-X, STR. 31-42.

Pocock, J.G.A. „The ideal of citizenship since classical times“, In: Beiner, R. (ed). (1995) Theorizing citizenship. New York: State University of New York press, pp. 29-53.

Podunavac, Milan (2001) Princip građanstva i poredak politike. Beograd: Fakultet političkih nauka i Čigoja štampa.

Rols, Džon (1998) Politički liberalizam. Beograd: Filip Višnjić.

Sládeček, Michal (2001-2002) “Pojmovno određenje političke zajednice”, Filozofija i društvo XIX/XX, str. 179-192.

Svift, Adam (2008) Politička filozofija. Beograd: Clio.

Tenis, Ferdinand (1987) “Zajednica i društvo”. U: Formalizam u sociologiji, ur. Lukić, Radomir, str. 235-241.

Vasiljević, Jelena (2013) „Građanstvo: Neka razmatranja o klasičnim osnovama i savremenim trendovima rekonceptualizacije“, Filozofija i društvo XXIV (3), str. 135155.

Vasiljević, Jelena (2016) Antropologija građanstva. Novi Sad: Mediterran Publishing.

Veber, Maks (1976) Privreda i društvo 1-2. Beograd: Prosveta.

Vujačić, Ilija (2002) Politička teorija. Beograd: Čigoja štampa.

Vujaćić, Ilija (2007) „Oblici građanstva i multikulturalizam“. U: Položaj nacionalnih manjina u Srbiji, ur. Stanovčić, Vojislav. SANU. Beograd: 2007. 


\title{
CITIZENSHIP WITHIN LIBERALISM AND COMMUNITARISM: HISTORICAL DEVELOPMENT AND INTERFERENCES
}

\begin{abstract}
The focus of the study is the analysis of the historical genesis of two classical traditions of citizenship: communitarism and liberalism. Both traditions owe their origins and foundations to ancient civilizations (Greece or Rome), but they are fully developed in the new century, through modern philosophical and political speculations. In modern age, both communitarism and liberalism will be an important subject of controversy and will be embedded in different ideologies or interfere with them during the nineteenth and twentieth centuries, which continues today. Modern pluralistic societies, however, point to the lack of both civic traditions when it is necessary to find favorable solutions to civic inclusion of different cultural groups and identities. At the end of the twentieth century, there was a renewed interest in citizenship theory and a number of new models and theoretical proposals were emerging, including groupdifferentiated citizenship, as well as other concepts, some of which are cited in the paper. All of them represent a critical review of classical civic traditions, but nevertheless it shows that no new concept can theoretically or practically be completely isolated from communitarism and liberalism and their theoretical achivements.
\end{abstract}

Keywords: Citizenship, communitarism, liberalism, political community, republicanism. 